\title{
Report on the Effect of Drought Condition on Livestock Production
in North Western State
}

\author{
Mamrman Jrya \\ Chief Veterinary Officer, \\ Ministry of Natural Resources, \\ North Western State, \\ Sokoto.
}

\section{General Introdection}

THE North Western State of Nigeria is situated generally between longitudes $3^{0}$ and $8^{\circ}$ East of Groenwich $0^{\circ}$ Meridiam and between latitudes $9^{\circ}$ to $14^{\circ}$ North of the Equator. This geographical position places the state in a variety of Vegetational zones ranging from the regions botdering the rain forest areas of the South, Northwards through thick Savannah, open Savannah to open semi-desert areas on the northern borders. Generally speaking all areas above the 12th parallel northwards are susceptible to drought conditions of varying degrees every year. This area also contains the bulk of the livestock population which annually results in varying degrees of overgrazing in the available grazing areas which are limited to the few river valleys. The annual rainfall varies between $35^{\text {" }}$ to $40^{\prime \prime}$ in the southern reaches to between $15^{\prime \prime}$ to $25^{\prime \prime}$ in the northern reaches of the state. The southern areas also generally lie within the tsetse fily belt and consequently, although this area contains adequate grazing most of the year round, it is harzardous to livestock during most times of the year. In the height of the dry season however large numbers of livestock usually migrate to the southern parts for grazing in spite of the risks from trypanosomiasis.

\section{Livestock Distribution}

The present development plan for Livestock and Veterinary Services for the state was based on the report by the Special Duties Officer's Committee on the Distribution of Assets and Liabilities of the former Government of Northern Region which was largely based on vaccination figures compiled during J.P. 15 Project for Rinderpest Campaign, 1963-66. Comparative Livestock figures from this report are given for the Northern States in Tables 1 and 2 .

TABLE 1

Urestock units in the Northern States

\begin{tabular}{|c|c|c|c|c|}
\hline State & $\begin{array}{l}\text { Livestock } \\
\text { tenits (q) }\end{array}$ & $\begin{array}{c}\text { Percentages } \\
\text { of total } \\
\text { Wivestock } \\
\text { unitx }\end{array}$ & $\begin{array}{l}\text { Denuity per } \\
\text { 19. mile }\end{array}$ & $\begin{array}{l}\text { Weighted } \\
\text { nutio of } \\
\text { livertoct } \\
\text { units (b) }\end{array}$ \\
\hline $\begin{array}{l}\text { North Central } \\
\text { Kaso } \\
\text { North Eastern } \\
\text { Benue Plateau } \\
\text { C Weit (Kwara) } \\
\text { North Western }\end{array}$ & $\begin{array}{r}1,024,642 \\
1,164,384 \\
4,006,269 \\
920,524 \\
161,606 \\
2,161,912 \\
\end{array}$ & $\begin{array}{r}10.9 \\
12.3 \\
42.4 \\
9.8 \\
1.6 \\
23.0\end{array}$ & $\begin{array}{r}38 \\
70 \\
38 \\
23 \\
6 \\
33 \\
\end{array}$ & $\begin{array}{r}5 \\
6 \\
21 \\
6 \\
1 \\
11 \\
\end{array}$ \\
\hline TOTAL & $9,439,337$ & & & \\
\hline
\end{tabular}


It is worthy to note that the only Official Records available for Livestock populations are from Annual Jangali Tax figures obtained from Local Authorities. For many well known reasons connected with administrative defects in Local Authority assessments we know that Jangali figures are a gross under-estimation and most likely represent only about $1 / 3$ of the actual livestock population. Livestock populations from Jangali figures for the year $1971 / 72$ by divisions and annual comparative figures from $1968 / 69$ to 1971/72 are shown in tables 3 and 4 . The constant tendency of the comparative figures is well illustrated for especially cattle which are the items of taxation. From these figures estimated projected correct livestock figures for North Wsetern State at the moment are as follows

$\begin{array}{lr}\text { Cattle } & -2,500,000 \\ \text { Sheep } & -1,500,000 \\ \text { Goats } & -4,100,000 \\ \text { Horses }- & 158,000 \\ \text { Donkeys }- & 810,500 \\ \text { Camels }- & 52,000\end{array}$

These figures agree roughly with this Ministry's C.B.P.P. Vaccination figures in the case of cattle currently involved with Mass International CBPP Eradication Campaign.

The following Administrative Divisions are generally affected by drought conditions much more than the rest of the State:

\begin{tabular}{|l|r|r|r|r|r|}
\hline \multirow{2}{*}{ Divisions } & \multicolumn{3}{|c|}{ Projected Livestock Population, 1971/72. } \\
\cline { 2 - 6 } & Cattle & \multicolumn{1}{|c|}{ Sheep } & Goats & Horses & Donkeys \\
\hline Sokoto & $1,007,100$ & 374,823 & $3,009,870$ & 38,883 & 619,158 \\
Argungu & 147,270 & 51,357 & 212,412 & 9,618 & 36,936 \\
Gwandu & 356,445 & 323,820 & 405,768 & 20,649 & 142,260 \\
\hline TOTAL & $1,510,815$ & 750,000 & $3,628,050$ & 69,150 & 798,354 \\
\hline
\end{tabular}

TABLE 2

Number of cattle, sheep and goats in the Northern State

\begin{tabular}{|l|r|r|r|r|r|r|r|r|r|r|}
\hline \multicolumn{1}{|c|}{ State } & $\begin{array}{r}\text { Area } \\
\text { sq. } \\
\text { miles }\end{array}$ & Cattle & $\%$ & $\begin{array}{c}\text { Den- } \\
\text { sity } \\
\text { per } \\
\text { sq } \\
\text { mile }\end{array}$ & Sheep & $\%$ & $\begin{array}{r}\text { Den- } \\
\text { sity } \\
\text { per } \\
\text { sq. } \\
\text { mile }\end{array}$ & Goats & $\%$ & $\begin{array}{c}\text { Den- } \\
\text { sity } \\
\text { per } \\
\text { sq. } \\
\text { mile }\end{array}$ \\
\hline North Central & 26,754 & 708,377 & 9.7 & 26 & 300,743 & 8.6 & 11 & $1,205,561$ & 18.9 & 45 \\
Kano & 16,630 & 783,200 & 10.7 & 46 & 541,145 & 15.5 & 33 & $1,229,492$ & 19.3 & 74 \\
North East & 104,942 & $3,213,014$ & 44.1 & 31 & $1,501,721$ & 43.1 & 14 & $2,089.123$ & 32.7 & 20 \\
B/Plateau & 39,271 & 668,800 & 9.2 & 17 & 639,926 & 18.3 & 16 & 458,716 & 7.2 & 12 \\
C/West (Kwara) & 28,672 & 115,220 & 1.5 & 4 & 107,409 & 3.1 & 4 & 112,671 & 1.7 & 4 \\
North West & 65,004 & $1,804,418$ & 24.8 & 28 & 398,913 & 11.4 & 6 & $1,288,818$ & 20.2 \\
\hline TOTAL & 281,273 & $7,289,996$ & & & $3,489,875$ & & & $6,384,381$ & \\
\hline
\end{tabular}




\begin{tabular}{|c|c|c|c|c|c|c|c|c|c|c|c|c|}
\hline ڤ్ & 유 & 1 & 1 & 1 & 1 & 1 & 1 & 1 & 1 & 1 & & \\
\hline 气े & 㐫 & $\infty$ & 1 & 1 & $\underset{m}{\infty}$ & 1 & 1 & ఫ్ల & $\begin{array}{l}\hat{6} \\
\infty \\
i\end{array}$ & $\frac{ \pm}{m}$ & $\underset{r}{\stackrel{Z}{g}}$ & त̃ \\
\hline 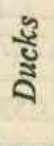 & $\begin{array}{l}\text { I } \\
\infty \\
-\end{array}$ & ন্ర & 1 & 1 & $\begin{array}{l}\text { Jै } \\
\text { i }\end{array}$ & 1 & 1 & $\stackrel{\text { }}{2}$ & $\frac{\bar{\alpha}}{\bar{m}}$ & స్ & 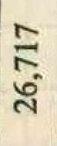 & ते \\
\hline है & $\begin{array}{l}\text { హ̆ } \\
\text { लn }\end{array}$ & $\frac{\text { ㅁํ }}{\text { ते }}$ & 1 & 1 & 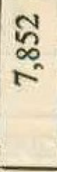 & 1 & 1 & $\frac{\sigma}{\sqrt{n}}$ & $\begin{array}{l}\bar{b} \\
\text { బิ } \\
\text { a }\end{array}$ & $\begin{array}{l}\overline{5} \\
\text { ô } \\
\text { î. }\end{array}$ & 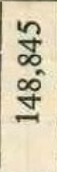 & त̂ \\
\hline$\stackrel{0}{20}$ & స్ & 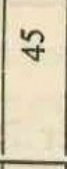 & 1 & 1 & 1 & 1 & 1 & 1 & 1 & $\bar{\lambda}$ & $\begin{array}{l}\mathscr{\tilde { n }} \\
\text { m. }\end{array}$ & $\begin{array}{l}\text { ñ } \\
\text { of } \\
\text { లn }\end{array}$ \\
\hline ฮัँ & - & $\mathbb{N}$ & బิ & $m$ & - & $\begin{array}{l}\text { đั } \\
\text { fே }\end{array}$ & 福 & 1 & 1 & 1 & 1 & $\frac{\stackrel{\rho}{m}}{\dot{q}}$ \\
\hline 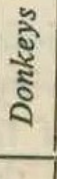 & 웅 & $\begin{array}{l}\infty \\
\infty \\
i \\
\text { iv }\end{array}$ & 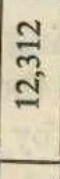 & 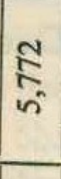 & $\begin{array}{l}\overrightarrow{\widehat{6}} \\
\dot{\sigma}\end{array}$ & 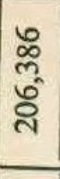 & 䃾 & లే & ช్ర & m & $\stackrel{n}{\text { 그 }}$ & 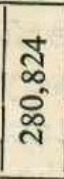 \\
\hline ปี & 1 & 1 & 1 & 1 & 1 & స্ল & 1 & 1 & 1 & $\tilde{\lambda}$ & 1 & $\begin{array}{c}\hat{j} \\
\hat{\sim}\end{array}$ \\
\hline ญे & ल & సิ & $\begin{array}{l}\text { तె } \\
\text { ñ }\end{array}$ & $\stackrel{\circ}{\stackrel{0}{+}}$ & $\stackrel{n}{\sim}$ & $\begin{array}{l}\vec{\swarrow} \\
\text { ㅇ }\end{array}$ & $\begin{array}{l}2 \\
\infty \\
\infty \\
0\end{array}$ & ฬे & 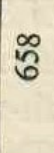 & 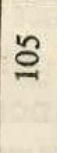 & $\begin{array}{l}\overline{8} \\
\stackrel{0}{\circ}\end{array}$ & $\frac{g}{2}$ \\
\hline ปัँ & 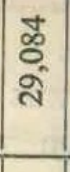 & $\begin{array}{l}\text { き } \\
\text { こ్ }\end{array}$ & $\begin{array}{l}\text { ¿े } \\
\infty \\
\overbrace{}^{\prime}\end{array}$ & $\begin{array}{l}\text { กี } \\
\text { สี }\end{array}$ & $\begin{array}{l}\text { fo } \\
\text { f }\end{array}$ & ๙ू. & 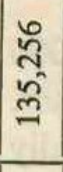 & $\begin{array}{l}\text { ذे } \\
\text { త్ }\end{array}$ & $\begin{array}{l}\overline{8} \\
\text { i }\end{array}$ & $\underset{6}{\mathbb{6}}$ & $\begin{array}{l}\text { ָ̊ } \\
\text { ָิ }\end{array}$ & 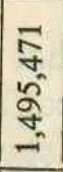 \\
\hline $\begin{array}{l}\text { ญे } \\
\text { ऊँ }\end{array}$ & बे & ‡ & Е & 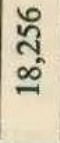 & $\begin{array}{l}\text { के } \\
\text { o } \\
\text { लु }\end{array}$ & ڤે & $\begin{array}{l}\text { वे } \\
\text { डे } \\
\text { - }\end{array}$ & $\frac{\vec{n}}{\vec{f}}$ & 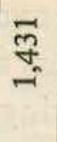 & $\begin{array}{l}\text { ส̃ } \\
\infty \\
\sigma \\
\text { on }\end{array}$ & $\begin{array}{l}\infty \\
\infty \\
\infty \\
\infty \\
0\end{array}$ & $\begin{array}{l}\frac{\pi}{\infty} \\
0 \\
\mathbb{d} \\
0\end{array}$ \\
\hline కี & 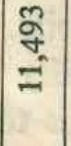 & 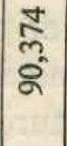 & $\begin{array}{l}8 \\
8 \\
9\end{array}$ & $\begin{array}{l}\infty \\
\infty \\
\infty \\
\text { లీ }\end{array}$ & 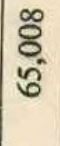 & $\begin{array}{l}8 \\
\text { ڤ్ } \\
\text { ల్ }\end{array}$ & $\begin{array}{l}\frac{N}{\infty} \\
\infty \\
= \\
=\end{array}$ & $\begin{array}{l}n \\
\infty \\
\infty \\
\text { ని }\end{array}$ & ᄋ్ & \begin{tabular}{l}
$\stackrel{8}{8}$ \\
ले \\
\multirow{2}{*}{}
\end{tabular} & $\begin{array}{l}\infty \\
0 \\
0 \\
\tilde{N} \\
\tilde{=}\end{array}$ & 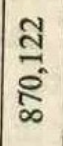 \\
\hline 芯 & 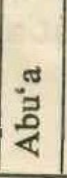 & 点 & $\begin{array}{l}\text { 总 } \\
\text { 总 } \\
\text { 究 }\end{array}$ & స్그 & 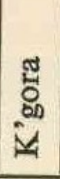 & 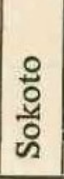 & 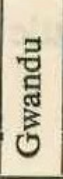 & $\frac{\pi}{\circ}$ & 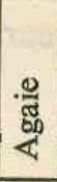 & 苂 & 兽 & 푱 \\
\hline
\end{tabular}


TABLE 4

Comparison of Livestock Population in North Western State (1968 - 1972)

\begin{tabular}{|l|r|r|r|r|}
\hline \multicolumn{1}{|c|}{ Livestock } & \multicolumn{1}{c|}{$1968-69$} & $1969-70$ & $1970-71$ & $1971-72$ \\
\hline Cattle & 717,986 & $772,880+$ & $910,602+$ & $870,122-$ \\
\hline Sheep & 467,698 & $475,616+$ & $198,079-$ & $364,874+$ \\
\hline Goats & $1,371,632$ & $1,469,383+$ & $1,100,428-$ & $1,495,471+$ \\
\hline Horses & 46,831 & $42,920-$ & $87,727+$ & $33,109-$ \\
\hline Donkeys & 81,420 & $268,589+$ & $261,053-$ & $280,824+$ \\
\hline Camels & 4,394 & $3,819-$ & $12,179+$ & $49,130+$ \\
\hline Pigs & 12,006 & $5,091-$ & $21,762+$ & $38,233+$ \\
\hline Poultry & 280,624 & $290,080+$ & $732,522+$ & $635,410-$ \\
\hline
\end{tabular}

Although the most affected areas of these divisions are the border districts such as Sabon Birni, Gada, Goronyo, Gwadabawa and Tangaza in Sokoto Division and Yeldu, Kangiwa, Kamba in Argungu Division the effects were apparent in most districts everywhere. For the northern most districts affected traditionally the bulk of the resident cattle and sheep normally migrate into Zamfara Forest, North Central State and beyond, in the case of north-eastern districts of Sokoto, and into lower reaches of Sokoto/ Rima Valley, Yauri and Southern parts of the State in the case of north-western districts of Sokoto and Argungu Divisions.

It is estimated that about $2,063,000$ Livestock mainly cattle, sheep, horses, donkeys and camels stay behind normally in the drought-affected areas every dry season. This number includes migrant Rahahi cattle from neighbouring Niger Republic and in fact observations show that the majority of cattle in these parts between February to May are mainly migrant Rahaji. Note, only Cattle and Sheep populations are usually involved in nomadic migrations. This year cattle from Niger Republic have been observed as far down as Benue Plateau and Kwa1a States.

\section{General Observations in Drought Areas}

During the periods between January to April the following observations were made by Staff of this Ministry through constant trips to the districts of Sabon Birni, Isa, Goronyo, Gada, Gwadabawa and Tangaza:

(1) Most of the land was completely barren.

(2) Most of the area was covered with loose sand and in April, May and June, sandstorms were a common feature.

(3) There was generally an acute water shortage with wells of less than $100 \mathrm{ft}$. mostly dry as early as March. Along the Rima River bed, the river has dried up completely except for small ponds and hand-dug water pits.

(4) Generally there are absolutely no pastures to graze the livestock and scanty vegetation has no green leaves at all. 
(5) Progressive emaciation was apparent in all livestock until in May/ June when alarming reports of mass livestock mortality started reaching the Ministry. Veterinary staff investigated the mass mortality report in Sokoto, Argungu and Gwandu Divisions.

Report on mass mortality of livestock in drought-affected areas of North Western State

The teams of Veterinarians and Divisional Livestock Officers were mobilised to investigate the mass mortality reports. The following observation and statistics came to light:

(1) In Tangaza district 468 cattle and 419 sheep and goats were examined. Out of these, 97 cattle and 157 sheep and goats were lost due to starvation.

(2) In Anka district, the following animals were investigated: cattle 726 , sheep and goats 589 . Losses observed due to starvation were
73 cattle, and 71 sheep and goats in May/June.

(3) In Zurmi district a total of 1,463 cattle and 2,344 sheep and goats were examined. In these herds 250 cattle and 985 sheep and goats were lost in May/June due to starvation.

(4) Gusau and Kaura Namoda districts, discussions with District and Village Heads as well as Fulani cattle owners reveals an estimated $20 \%$ loss of livestock.

(5) Gummi district, out of 1,362 cattle and 432 sheep and goats examined, there were 378 cattle and 76 sheep and goats lost by starvation.

(6) In Argungu Division there were reports of mass deaths generally. Many herds were examined. Of 1,052 cattle deaths 225 were recorded due to starvation.

(7) In Gwandu Division the team investigated herds containing a total of 8,291 cattle and found a mortality of 759 .

\begin{tabular}{|l|c|c|c|}
\hline \multicolumn{1}{|c|}{ Division } & $\begin{array}{c}\text { No. of livestock } \\
\text { investigated } \\
\text { cattle, sheep and } \\
\text { goats }\end{array}$ & Mortality & Percentage \\
\hline Sokoto & 7,803 & 2,087 & $30 \%$ \\
Argungu & 1,052 & 225 & $21 \%$ \\
Gwandu & 8,291 & 759 & $9 \%$ \\
\hline TOTAL & 17,176 & 3,071 & $18 \%$ \\
\hline
\end{tabular}

\section{Summary of Investigations}

During investigations also, the following observations were made:

(1) There were a very large number of cattle which were downers (too weak to stand), the eventual fate of these cattle cannot be ascertained, but it is believed many will die making the eventual percentage mortality higher.
(2) There was a terrific increase of dry meat trade all over the three divisions of Sokoto, Argungu and Gwandu and also a sharp reduction of price down to $\mathrm{N} 30.00$, $\$ 10.00$ and $\$ 1.00$, respectively for cattle, sheep, and goats in the rural areas. The situation is much the same all over the three divisions and it is estimated that there is an 
over all loss of $20 \%$ of livestock in Sokoto, Argungu and Gwandu Divisions. In many of the countryside, carcases of horses, donkeys and camels can be seen strewn about in the bush around the villages. Many carcases were examined at post mortem with stomach and gut compacted with sand.

Summary of Estimated Mortality

\begin{tabular}{|l|c|c|c|}
\hline \multicolumn{1}{|c|}{ Division } & Cattle & Sheep/Goats & Horses/Donkeys \\
\hline Sokoto & 201,420 & 676,937 & 121,608 \\
Argungu & 29,454 & 52,744 & 9,111 \\
Gwandu & 71,289 & 142,918 & 32,581 \\
\hline TOTAL & 302,163 & 875,599 & 163,300 \\
\hline
\end{tabular}

\section{Government Drought Relief Efforts}

In December 1972, the government of North Western State released the sum of $\mathrm{N} 300,000$ to be directed for immediate livestock drought relief even before aid came from the Federal Government. The Federal Grant of 1.125 million Naira came late at the end of the financial year and therefore the funds could not be immediately used.

The following relief materials were procured and distributed to the drought affected areas all over the state:

(1) Assorted dry fodder i.e. cowpea hay, groundnut hay, grass hay and farm residues to the amount of 340,00 bundles of approximately 1,500 tons.

(2) 2,500 tons of cotton seed.

(3) 100 tons of groundnut cake.

(4) 2,000 blocks of Pfizer mineral salt licks.

Government policy to sell all relief materials at $50 \%$ subsidy created many initial difficulties with relief work especially in the case of dry fodder hay, but eventually Government released this item for free distribution. Also access to all the drought affected areas was very difficult and a lot of the materials could not be readily made available to the needy in the very remote areas.
Mention must be made here of the efforts of the Veterinary Division of the Ministry of Natural Resources of the long term projects being undertaken to combat drought and aid animal husbandry in the rural areas. These efforts include the present plan for 116 boreholes and livestock watering yards distributed in the most severely drought affected districts of Sokoto, Gwandu and Argungu Divisions at a total cost of about 1.6 million Naira. A further 133 boreholes are being planned for the future at an estimated cost of 2.66 million Naira. A 1.0 million Naira project is also in the pipeline for a Rima Valley drought alleviation project which will also include some borehole and dam constructions in the area for livestock use.

The ministry's small dam construction project has also been intensified and presently the Government has commissioned a Firm of Engineering Consultants for a surface water resources survey from which very useful information can be compiled to aid our dam construction programme.

\section{Recommendations for the Future}

The 1972/73 drought and the relief undertaken has given all concerned an opportunity to study the problems involved. Future plans are essential to be 
considered to enable prompt and timely intervention to prevent more serious disaster to the livestock industry in this State. The following recommendations are worth serious attention:

(1) There is need to intensify such programmes as establishment and improvement of grazing reserves and range management schemes to provide areas of adequate pasture and water where livestock owners can be advised to move to in such disasters.

(2) There is need for Government to embark on programmes of direct fodder production and possibly establish strategic fodder reserves in various divisions every year, in advanced agricultural crops in the same way as food crops. Since the bulk of the Fulanis own no land it is government responsibility to cater for the welfare of these people in order to safeguard their livestock which form an important item in the economy of the country.

(3) There is need to intensify reforestation of vast areas in the Sahelian zones of this state and all forest reserves should be regarded officially and otherwise as part of livestock amenities as far as grass pastures within them are concerned.

(4) Government should intensify all projects for provision of adequate water supplies in the rural areas. These can take the form of the present borehole and dam constı uction programmes.

(5) The Rural Water Supply Section of Ministry of Works and Survey should be immediately expanded and staffed to look seriously into the problem of providing clean and permanent water to all rural pupulation and livestock. The present well-sinking programme is grossly inadequate.

(6) The supplimentary feeding programme of the ministry of Natural Resources should be expanded and intensified. A Government feed mill is necessary to be established. Transport and storage of facilities have to be also intensified.

(7) Rural feeder roads have to be improved and increased to make more rural areas more accessible to rural workers. 